\title{
Probit Analysis of Women's Access to Agricultural Inputs in Bosso Local Government Area, Niger State, Nigeria
}

Olaleye, R. S , Ibrahim, M. and Ojo, M. A

Dept. of Agric Econs. and Extension Tech

Federal University Of Technology

P.M.B.65, Minna, Niger State.

E-mail address: olaleyerotimidavid@yahoo.com

\begin{abstract}
The title of the study is Probit analysis of women's access to agricultural inputs in Bosso Local Government Area of Niger State, Nigeria. The specific objectives are to identify the socio-economic characteristics of the women farmers and examine their sources of agricultural inputs as well as their accessibility to these inputs, including problems they faced in accessing the inputs. To achieve these, a total of 140 women farmers were purposively selected from 10 wards of the LGA. Validated Interview Schedule with reliability coefficient of 0.87 was used to collect relevant data from the respondents. Findings revealed that majority of the women farmers were within active productive age of between 21 and 50 years, mostly without formal education (64.3\%) and married(81.4\%).Also, most of the women engaged in farming either as a full or part time farmers. Similarly, few women had regular access to credit facilities and fertilizer. The problem adduced by the women farmers were discrimination against them and poor rural roads. Furthermore, probit analysis showed that $64 \%$ variation in the adequacy of inputs purchased by the women farmers was significantly explained by their access to labour, fertilizer, agro-chemicals and distance between individual farms and points of sales of agricultural inputs. It is recommended that women farmers should be encouraged to form co-operative groups in order to enhance their access to relevant inputs. Similarly, the Local Government Authority should try and rehabilitate the existing rural roads in addition to the construction of other roads with a view to linking the various villages and towns for easy transportation.
\end{abstract}

\section{INTRODUCTION}

The issue of gender sensitivity cannot be over emphasized in the development of agriculture, especially in relation to division of labour according to task and varieties of crops grown (Ayieko, 1986). Generally, women play a crucial role in farming and it is estimated that about 60 to 80 percent of all agricultural production activities are carried out by women in the continent of Africa. According to Ochoon (1993), women combine domestic works with subsistence farming, including fishing, processing and sales of agricultural produce and products. 
Furthermore, Nigerian women have been found to contribute 60 percent of labour force, produce 80 percent of food, earn 10 percent of monetary income and own one percent of farm assets. However, women's substantial contributions to agriculture continue to be systematically marginalized and underestimated in commercial agriculture, economic analyses and policies. Similarly, women do not receive equitable opportunities or decision-making privileges as men, and they often encounter more difficulties than men in gaining access to or control over land, credit facilities, technical information and commercial market outlets (Jiggins et al , 1984 ).

Similarly, Akande and Igbi,(1984) reported that only few female benefited from formal credit facilities given out to farmers for larger scale agricultural production, and concluded that access to credit facilities promote high productivity.

Regardless of these observations and the immense contributions of women to economic advancement of both household and national economies, women are constantly faced with diverse socio-economic, political and cultural factors which have continued to hinder the realization of their potentials in agricultural production. These factors had resulted in their poor and inadequate access to production resources and services (Gabriel, 1993). Moreover, the problems of inputs availability at the required period and at reasonable costs have continued to affect the optimal increase in agricultural production by women farmers.

Therefore, the general objective of this study is to examine women's access to agricultural inputs using Probit analysis.

Specific objectives are to;

(i) identify the socio - economic characteristics of the women farmers,

(ii) examine sources and accessibility of women farmers to agricultural inputs and

(iii) ascertain problems being faced by women farmers in accessing agricultural inputs.

\section{Hypothesis}

1. There is no significant difference between women's access to various agricultural

Inputs and the adequacy of inputs acquired for their agricultural productions

\section{METHODOLOGY}

The study was conducted in Bosso Local Government Area of Niger State, Nigeria.

Different numbers of women farmers were purposively selected from each of the ten wards of the LGA to give a total of 140 respondents (that is, Bosso Central $1=13$, Bosso Central $2=13$, Beji $=14$, Maikunkele $=15$, Maitunbi $=14$, Kampala $=15$, Kodo $=13$, Chanchaga $=13$, Garatu $=15$ and Shatta $=15$ respondents). The instrument used for data collection was Interview Schedule. This was subjected to both validity and reliability tests, (Test-retest method, $r=$ 0.87).Subsequently, data collected were analyzed using descriptive ( frequency, percentages and means ) and inferential statistics ( Probit Analysis ) at 5\% significant level.

\section{Measurement of variables}

Age was measured in years, farm size ( $\mathrm{Ha}$ ), access to land, labour, credit facilities, fertilizer and agro-chemicals were measured on 2-point Likert Scale (Regularly $=2$ points, Occasionally= 1 point), while rate of gender discrimination against women and distance from points of inputs purchase to individual locations were on 3-point Likert Scale (Always $=3$, 
Journal of Agricultural Extension

Vol. 13 (2) December 2009

Occasionally $=2$ and None $=1$ point) and (very far $=1$, far $=2$ and not far= 3 points) respectively.

Probit analysis equation is expressed in Exponential explicit model form;

$\ln Y=b_{0}+b_{1} X_{1}+b_{2} X_{2}+b_{3} X_{3}+b_{4} X_{4}+b_{5} X_{5}+b_{6} X_{6}+b_{7} X_{7}+b_{8} X_{8}+b_{9} X_{9}+U$

where

In = natural logarithm

$\mathrm{b}_{\mathrm{o}}=$ constant

$\mathrm{U}=$ error term

$\mathrm{X}_{1}=$ age

$\mathrm{X}_{2}=$ access to labour

$\mathrm{X}_{3}=$ access to land

$\mathrm{X}_{4}=$ farm size holding

$\mathrm{X}_{5}=$ access to credit facilities

$X_{6}=$ rate of gender discrimination against women in the sales of inputs to farmers

$\mathrm{X}_{7}=$ distance from points of inputs purchase to individual locations

$\mathrm{X}_{8}=$ access to fertilizers

$\mathrm{X}_{9}=$ access to agro - chemicals

Dep.Var. $(Y)=$ adequacy of inputs purchased for agricultural production (dummy)

$\mathrm{X}_{1}$ to $\mathrm{X}_{9}=$ Independent Variables

\section{RESULTS AND DISCUSSION}

\section{Socio - economic characteristics of the women farmers}

Findings in Table 1 showed that majority of the sampled women farmers were within the productive age of between 21 and 50 years, while only few of them were above 50 years old(8.6\%). It implies that young women participate in agricultural activities than the old women. Similarly, most of the women farmers did not have formal education (65\%) and this may adversely affect their abilities to access relevant information and opportunities relating to inputs acquisition. In addition to this, $81.4 \%$ of the sampled women farmers were married and this may have positive effect on their access to farm land and family labour, especially through their husbands and children respectively. 
TABLE 1: Socio - Economic Characteristics of Women Farmers

\begin{tabular}{lcc}
\hline Variables & Frequency & Percentage \\
\hline & & \\
Age ( Years ) & 23 & 16.4 \\
Below 21 & 65 & 46.42 \\
$21-40$ & 40 & 28.6 \\
$41-50$ & 12 & 8.6 \\
51 and above & 140 & 100.0 \\
Total & & \\
Highest educational level attainment & 50 & 35.7 \\
Islamic education & 49 & 35.0 \\
Formal education & 41 & 29.3 \\
Adult education & 140 & 100.0 \\
Total & & \\
Marital status & 114 & 81.4 \\
Married & 9 & 6.4 \\
Single & 17 & 12.1 \\
Widow & 140 & 100.0 \\
Total & & 48.5 \\
Occupation & 68 & 20.7 \\
Farming / other economic activities & 29 & 30.7 \\
Farming / business & 43 & 100.0 \\
Farming / civil servant & 140 & \\
Total & & \\
\hline
\end{tabular}

Source: Field Surrey

\section{Sources and accessibility to agricultural inputs by women farmers}

This section presents findings on various sources of agricultural inputs and women relative access to them. The resources under study include land, labour, credit facilities, fertilizer and agro - chemicals as well as the adequacy of acquired inputs for their farming activities.

Findings in Table 2 revealed that the sampled women farmers had access to farm land but their control over this land in terms of frequency of access and size of holding had limitations because not every one of them had regular access. For instance, $89.3 \%$ of women farmers had regular access and others did not. Also, majority of the women did not have more than 3 hectares of farm land and all these may hinder their desires to cultivate larger farm land. 
Journal of Agricultural Extension

Vol. 13 (2) December 2009

TABLE 2: Women's Access to Land

\begin{tabular}{lcc}
\hline Variable & Frequency & Percentage \\
\hline & & \\
Frequency of access & 125 & 89.3 \\
Regularly & 15 & 10.7 \\
Occasionally & 140 & 100.0 \\
Total & & \\
Source & 43 & 30.7 \\
Through purchase & 66 & 47.1 \\
Inheritance & 22 & 15.7 \\
Gift & 9 & 6.4 \\
No response & 140 & 100.0 \\
Total & & \\
Size of farm holding (Ha) & 58 & 41.4 \\
1 Ha and below & 75 & 53.6 \\
$2-3$ & 7 & 5.0 \\
$4-5$ & 140 & 100.0 \\
Total & & \\
\hline
\end{tabular}

Source: Field survey

Moreover, Findings in Table 3 indicated that only 22.2percent of the sampled women had regular access to credit facilities, with formal lending institutions and government (Local government) giving financial support to only 10.7 and 25.7 percent of women farmers respectively. The inability of women farmers to access credit facilities through lending institutions might be due to administrative bureaucracy which usually characterized these institutions. It was further revealed that major source of labour for farm works rested, to a greater extent on the family members as indicated by 71.4 percent of the women farmers. This suggests that farming by the women is largely characterized by stress and drudgery which can hardly bring about desired maximum productivity and corresponding incomes. 
TABLE 3: Women's Access to Capital and Labour

\begin{tabular}{lcc}
\hline Variable & Frequency & Percentage \\
\hline & & \\
Frequency of access to capital & 31 & 22.1 \\
Regularly & 109 & 77.9 \\
Occasionally & 140 & 100.0 \\
Total & & \\
Major source of capital & 15 & 10.7 \\
Bank & 24 & 17.1 \\
Co-operative & 49 & 35.0 \\
Husband & 6 & 4.2 \\
Local money lender & 36 & 25.7 \\
Local government & 10 & 7.1 \\
None & 140 & 100.0 \\
Total & & 50.0 \\
Frequency of access to labour & 70 & 50.0 \\
Regularly & 70 & 100.0 \\
Occasionally & 140 & 28.5 \\
Total & & 71.4 \\
Major source of labour & 40 & 100.0 \\
Personal & 100 & \\
Family & 140 & \\
Total & & \\
\hline
\end{tabular}

Source: Field survey

In case of access to fertilizer and other agro - chemicals, it was found out that most of the women farmers acquired fertilizers from open markets, usually as member of a group because individual effort was not yielding adequate results. On the other hand, most women acquired their agro-chemicals through the State Agricultural Development Project and the advantage is that farmers are likely to have genuine products and positive results when compared with open markets where adulterated products may abound. In all 30 and 73.6 percents of the women farmers had regular access to fertilizers and relevant agro -chemicals respectively (Table 4). However, over one half $(57.1 \%)$ of the women farmers sampled complained of inadequate farm production resources and this may be due to some fundamental problems as revealed in this study. These problems include discrimination against women and distance from farm to points of sales. Based on observations, even those that were close to points of sales might also experience high cost of transportation due to poor access roads among others thereby increasing production cost. 
Journal of Agricultural Extension

Vol. 13 (2) December 2009

TABLE 4: Women Farmers Access to Fertilizer and Agro - Chemicals

\begin{tabular}{|c|c|c|}
\hline Variable & Frequency & Percentage \\
\hline \multicolumn{3}{|c|}{ Major source of fertilizer } \\
\hline Open market & 119 & 85.0 \\
\hline Gift & 21 & 15.0 \\
\hline Total & 140 & 100.0 \\
\hline \multicolumn{3}{|l|}{ Method of acquisition } \\
\hline As an individual & 40 & 28.6 \\
\hline As member of a group & 70 & 50.0 \\
\hline Both & 30 & 21.4 \\
\hline Total & 140 & 100.0 \\
\hline \multicolumn{3}{|c|}{ Frequency of access to fertilizer } \\
\hline Regularly & 98 & 70.0 \\
\hline Occasionally & 42 & 30.0 \\
\hline Total & 140 & 100.0 \\
\hline \multicolumn{3}{|c|}{ Major source of agro - chemical } \\
\hline Open market & 40 & 28.5 \\
\hline State ADP & 80 & 57.1 \\
\hline Gift & 20 & 14.2 \\
\hline Total & 140 & 100.0 \\
\hline \multicolumn{3}{|c|}{ Frequency of access to agro - chemicals } \\
\hline Regularly & 103 & 73.6 \\
\hline Occasionally & 37 & 26.4 \\
\hline Total & 140 & 100.0 \\
\hline \multicolumn{3}{|c|}{ Problems of acquiring agro - chemicals and fertilizers } \\
\hline \multicolumn{3}{|c|}{ Distance } \\
\hline Far & 90 & 64.3 \\
\hline Very far & 20 & 14.3 \\
\hline Not far & 30 & 21.4 \\
\hline Total & 140 & 100.0 \\
\hline \multicolumn{3}{|c|}{ Adequacy of inputs for agricultural production } \\
\hline Very adequate & 8 & 5.7 \\
\hline Adequate & 52 & 37.1 \\
\hline Inadequate & 80 & 57.1 \\
\hline Total & 140 & 100.0 \\
\hline \multicolumn{3}{|c|}{ Gender discrimination against women } \\
\hline Always & 98 & 70.0 \\
\hline Occasionally & 25 & 17.9 \\
\hline None & 17 & 12.1 \\
\hline Total & 140 & 100.0 \\
\hline
\end{tabular}

Source: Field survey 


\section{Probit analysis result of women's access to agricultural inputs}

The variables considered include the adequacy of inputs purchased for their desired farming activities(dependent variable), while the independent variables include age of the women farmers, their access to land, size of farm holding, access to labour, credit facilities, fertilizer, agro - chemicals, distance to points of purchase and rate of discrimination against women.

Based on the significant $F$-value, $R^{2}$ value and number of significant independent variables, the Exponential regression model was selected for the probit analysis.

The result in Table 5 showed a significant $F$-value at $5 \%$ significant level, $(F=2.398, P<$ 0.05).

It was also revealed that only $64 \%$ of the variation in the dependent variable was explained by the independent variables. Similarly, variables like access to labour $(\mathrm{t}=2.528$, $P<0.05)$, access to fertilizer $(t=0.785, P<0.05)$, access to agro - chemicals $(t=1.525$, $P<0.05)$ and distance from farm to points of inputs purchased $(t=-2.969, P<0.05)$ made significant contributions to the observed variation in the adequacy of inputs purchased for agricultural production. Specifically, the farther the distance from farm to points of sales inputs, the lower the adequacy of these inputs for agricultural production, which may be due to high cost of transportation and poor infrastructure in the rural areas.

TABLE 5: Probit Analysis Result

$$
\begin{aligned}
& R \text { value }=0.61 \\
& R \text { Square }=0.64 \\
& \text { Adjusted } R \text { Square }=0.52 \\
& F \text {-value }=2.398, P<0.05
\end{aligned}
$$

\begin{tabular}{lcccc}
\hline Variable & Beta coefficient & t-value & P- value & Decision \\
\hline Age & .094 & .984 & .33 & $\mathrm{NS}$ \\
Labour & .266 & 2.528 & .01 & $\mathrm{~S}$ \\
Land & .002 & .026 & .98 & $\mathrm{NS}$ \\
Farm size & .056 & .589 & .56 & $\mathrm{NS}$ \\
Capital & -.075 & -.889 & .38 & $\mathrm{NS}$ \\
Discrimination & .012 & -.138 & .89 & $\mathrm{NS}$ \\
Distance & -.255 & -2.969 & .00 & $\mathrm{~S}$ \\
Fertilizer & .116 & .785 & .00 & $\mathrm{~S}$ \\
Agro - chemical & .154 & 1.525 & .00 & $\mathrm{~S}$ \\
\hline
\end{tabular}

$N S=N o t$ sig, $S=\operatorname{sig}$ at $5 \%$ sig. level 
Journal of Agricultural Extension

Vol. 13 (2) December 2009

\section{CONCLUSION}

It can be concluded that access to labour, fertilizer, agro - chemicals and distance between individual farms to points of inputs purchased contributed significantly to the quantity of inputs acquired. It is recommended that women should organize themselves into groups to facilitate their access to agricultural inputs

\section{REFERENCES}

Akande,S.O.and Igbi, M.S (1984): Intra agricultural inequality; The male-female dichotomy; Ife Science Review. Vol.7,No.Land 2.pp.213-235.

Ayieko,M.A.(1986): “ Integration of women into farming system; research for faster technological change" Egerton University College Research Committee Paper No.11.pp.1-5

Gabriel,T.(1993): The human factor in rural development . Belharen Press, London,pp.73-79.

Jiggins, J. Samanta,R. and Olawoye, J.E.(1997): "Improving women's farmers access to extension services" In Improving agricultural extension. F.A.O. Rome.

Oochoo,A.E. (1993): "Improving African women and end hunger". African farmer. 